\title{
Environmental Vision of Saija's Characters in the Kelomang Novel by Qizink La Aziva
}

\author{
Ghulamin Khalim Subagiyo $^{(1)}$, Tommi Yuniawan ${ }^{(2)}$
}

(1) Universitas Negeri Semarang, Indonesia

(2) Universitas Negeri Semarang, Indonesia

*Correspondence to: khalimsubagiyo@gmail.com

\begin{abstract}
In the current literary realm, literary texts that present natural destruction events implicitly or explicitly are called apocalyptic literature. The main characteristic of apocalyptic literature is the emergence of characters who have heroic characters. The Kelomang novel written by Qizink La Aziva was chosen because it is one of the novel texts that does not only make the environment the setting, but also makes the environment a part of the story. The story in the Kelomang novel is characterized by apocalyptic. This study aims to find the environmental vision of Saija's character in the Kelomang novel by Qizink La Aziva. This study uses an ecocritical approach to apocalyptic literature. The data source of this research is the text of the Kelomang novel by Qizink La Aziva published by PT Gramedia Pustaka Utama in Jakarta in 2016. The data in this study is a text fragment of the Kelomang novel by Qizink La Aziva which allegedly contains Saija's environmental vision. The result of this research is that Saija has a vision of the environment to save the environment from the increasingly severe impacts of environmental damage, especially in his area, namely Banten.
\end{abstract}

Keywords: environment; environmental vision, novel; apocalyptic echocritic

Recommended citation: Subagiyo, G. K. \& Yuniawan, T. (2022). Environmental Vision of Saija's Characters in the Kelomang Novel by Qizink La Aziva. Journal of Innovation in Educational and Cultural Research, 3(1), 1-11.

\section{INTRODUCTION}

Since its inception, nature has been part of literature. Literature is able to actualize ecological issues and produce valid text analysis, both in literature and ecology (Rini, 2018). This is proven by the fact that there are not a few writers, especially from among poets, who use the diction of forests, sea, trees, etc. in their works. But along with development, literature has undergone many changes, so has nature. These two inseparable elements always seem to go hand in hand. Past literature is the face of the past and present literature is the face of the present world. Literature needs nature as its inspiration, while nature needs literature as a means of conservation. This is in accordance with Mahayana's opinion (Uniawati, 2014), that awareness of the importance of the environment in human life has long been echoed by writers. They always remind us of the importance of brotherhood with the world around them.

Experts from various fields of science have confirmed that humanity plays a major role in preventing human-caused environmental damage. So it can be emphasized that environmental damage which in turn has an impact on the sociocultural community is an example of a real problem that is disturbing to be investigated in literary studies. Wellek and Warren (Putri, 2017) discuss that the real relationship between literature and society is descriptive, not normative. Undeniably, the interruption of humankind to nature is excessive. The predominant human-centered worldview which we call 'anthropocentrism' has challenged the whole web of life (Adhikari, 2021).

As Ulrich Beck has argued (Tait, 2021), modern societies are by their very nature risk societies, and the risks they inadvertently create mark the limit of scientific understanding: often, those risks take the form of what Timothy Morton calls 'hyperobjects', 'massively distributed in time and space relative to humans', making it all the more difficult to understand, adapt to, or mitigate them.

Garrard (Sulistijani, 2018) said that the importance of ecological knowledge is not only to see the harmony and stability of the environment, but also to know human attitudes and behavior. Therefore, what the author can do is to convince and show that literature actually interacts with the lives of individuals in society (Asri, 2013). The apocalyptic vision of the environmentalists has put forward the spell of industrialization and scientific inventions has disturbed the harmony between nature and human. When 
literary writers rhetorically organize the vision of the environmentalists with their expertise, it mainly highlights the degenerating condition of nature and human as a whole (Chatterjee, 2021)

The study of Indonesian literature can be carried out by using an environmental perspective. Glothfelty (1996) states that his articles have inspired and commented on various parties regarding literary ecocritism. Ecocritic is the study of the relationship between literary studies and the physical environment (Kaswadi, 2015). Ecocriticism is one of the most relevant schools of thought in contemporary times. It is overlapping yet interconnected, philosophical yet scientific. Ecocriticism is not only a mere critical theory, but also a reality in which we are living and experiencing. Ecocriticism has such a wide scope since it belongs to different facets such as social, cultural, political, religious, or scientific (Mishra, 2021).

The literary works written by the author cover all aspects of life around them, in this case they are complex. Complex in the sense of containing and revealing every facet of the network of life (Afni, 2018). Learning from Freud that true literature is a product of the emotional maturity of writers.

Knowing the character of the characters in the novel is important because novel is not only beautiful but must also have benefits. One of these benefits is the messages through the characters in the story. The messages in the story will have an influence on the character education of the readers. You can imagine if education only produces intelligent people but without character, what is present is robots are versatile but heartless because they do has no character (Susanti \& Andriani, 2020).

In the current literary realm, literary texts that present natural destruction events implicitly or explicitly are called apocalyptic literature. Typically and stereotypically, the disobedient behavior of a child (human) to its mother (earth) is also a direct trigger for the emergence of an apocalyptic environment. The main characteristic of apocalyptic literature is the emergence of characters with heroic characters. Through this character, God's revelations are conveyed and visions of the future are conveyed, both directly and in disguise. The intended future vision is related to the future vision of the environment. A figure with an environmental vision is a figure who has an awareness of the importance of protecting the environment and preventing further environmental damage. These heroic characters are symbols of God's revelation in protecting the environment. Become a representative of God who provides benefits to the universe.

Apocalypticism is described as a genre born out of a crisis, designed to strengthen the resolve of marginalized communities by providing hope and a vision of freedom from its bonds. This hero figure is also one of the characteristics of apocalyptic literature. The heroine in the story is depicted on a journey accompanied by a guide. For this reason, an analysis of the elements of heroic characters can be done by observing (1) the selection of several great people in the past and making them heroes in the story; (2) the narrative of the hero's journey accompanied by a heavenly guide; and (3) generally the hero character's tour guide shows him interesting sights and provides comments (Sukmawan, 2013).

The Kelomang novel written by Qizink La Aziva is one of the novel texts that does not only make the environment the setting, but also makes the environment a part of the story. The Kelomang novel contains environmental criticism through the environmental vision of the figures in the form of rejection of a group of youths and residents of the Banten coast of the sea sand mining permit issued by Regent Jamaludin to PT Bintang Laut. The story in the Kelomang novel is characterized by apocalyptic.

Research related to ecocritic has been carried out by several researchers. However, apocalyptic ecocritical research in novels has not been found. Several studies that have relevance to this research are research conducted by Khristiyanti (2018) and Yuniawan (2019).

Research that has relevance to this research is research conducted by Khristiyanti (2018) with the title "Nature Environment Representation in 'Raudal Tanjung Banua Poetries': Exocriticism Review". The similarity between Khristiyanti's research and this research is the similarity of the approach used, namely the literary ecocritical approach. However, specifically this study uses literary ecocriticism as a model of apocalyptic studies.

The next research that has relevance to this research is research conducted by Yuniawan (2019) entitled "The Function of Exo-Lexicons in Conservation News Text Published in Mass Media". What Yuniawan's research has in common with this research is a critical study of environmental themes. The difference between Yuniawan's research and this research is that Yuniawan's research uses ecolinguistic theory or something that is more easily understood by linguistics with an environmental theme, whereas in this study it is not related to linguistics but rather environmental-themed literature.

Based on the search for relevant references, it can be seen that research related to literary ecocritic has indeed been researched. However, no one has researched the novel to find out the ecocriticism of apocalyptic literature on the environment through the environmental vision of the characters in the novels he wrote, so this study aims to find the environmental vision of the characters in the Kelomang novel by Qizink La Aziva using apocalyptic ecocritical studies. 


\section{METHOD}

Methodologically this research is a qualitative type of research, namely describing and analyzing phenomena, events, activities. social, attitudes, beliefs, thoughts in the Kelomang novel. The data source of this research is the text of the Kelomang novel by Qizink La Aziva published by PT Gramedia Pustaka Utama, in Jakarta in 2016. This study used an instrument in the form of a data card. The data in this study are in the form of a text fragment of the Kelomang novel by Qizink La Aziva which allegedly contains the character's environmental vision. Research data were obtained through literature study and heuristic reading techniques (Supriyanto, 2014). After the data is collected, it is classified based on the problem being studied. The data analysis technique used in this research is interactive analysis. The analysis of the model is divided into three components, namely data reduction, data presentation, and data levers.

\section{RESULTS AND DISCUSSION}

Agricultural settlers historically changed their attitude from seeing their crops as nature's blessing to seeing them as a reward being earned when they won the fight against nature (Sloots, 2020). Now, environmental degradation has become a fundamental problem and big task to tackle (Handique \& Bhattacharyya, 2021).

Novel is a work of fiction that contains the author imaginary world and is compiled as a whole so that it has elements which one and the other have a connection in harmonious relationship in telling the character's life so that only an event is displayed (Hartavi, 2021). The presentation of the results of the analysis of the heroic character according to the environmental vision is focused on Saija because the influence/contribution of the character is the greatest in the story. Saija is the main character in the Kelomang novel by Qizink La Aziva. He is the son of Yanto and Citra. Saija's name was inspired by the main character in Max Haveelar's novel. He is the head of the nature lovers group on his campus. As the head of the nature lovers group, he not only makes activities related to nature a hobby, but he has even more environmental responsibility related to his environmental vision, especially in his area, namely Banten. As can be seen in the following quote.

Sebagai ketua kelompok pecinta alam di kampusnya, Saija tak hanya sibuk mendaki gunung, menyusuri sungai, memanjat tebing, atau menjelajah gua-gua. Mahasiswa semester lima itu juga sering mengajak rekan-rekannya turun ke jalan untuk berdemo mengecam perusakan lingkungan atau melakukan aksi pelestarian lingkungan, seperti menanam bakau di pantai utara Kabupaten Serang yang terkikis abrasi, membersihkan aliran Sungai Ciujung dari tumpukan sampah, atau menanam pohon di lahan-lahan kritis. Aksi itu ia lakukan bersama aktivis lingkungan lainnya, atau paling tidak bersama tiga sahabatnya tadi. (Kelomang, 33)

Good character is created with good things, having good desires, and doing good, habits in ways of thinking and acting. The values of character education include sincerity or honesty, compassion, courage, affection, self-control, cooperation, hard work (Suryanto, 2021). Readers can give meaning to the literary works they read so that they can react or respond (Anggraini et.al, 2021). Saija knows very well that his love for the environment must also be balanced with actions that represent his love. Together with their three friends, namely Firman, Deden, and Ibnu, they together protect the environment or even improve the environment in the Banten area. According to the following quotation.

"Udah, nggak usah ribut. Sekarang waktunya beraksi!" ujar Saija yang sudah memegang plastik hitam besar. Laki-laki berambut sebahu itu langsung memunguti sampah yang berserakan di pinggir jalan dan memasukkannya ke kantong plastik. "Woi! Ngapain pada bengong! Cepat turun! seru Saija saat melihat ketiga rekannya masih beradu mulut. (Kelomang, 32)

Saija and his friends pick up trash scattered on the side of the road. He and his community friends started and moved from the smallest thing, namely cleaning the trash they saw scattered by the side of the road. Indeed, there is an agency that is obliged to care for and manage the environment. However, Saija and his friends from the nature lover community still care about the environment.

Saija also shares the same concerns with his friends and the coastal community in the Banten area. Anxiety about the fate of the environment in the area. This restlessness has made Saija and others have the same vision and ideals about how to save the environment. It seeks to balance the relationship between humans and various environmental systems on which humans depend, so that all parties receive treatment according to their sustainability. 
"Nelayan memiliki hak untuk menikmati laut yang asri sebagai tempat mereka mencari nafkah. Penambangan pasir laut bisa berdampak buruk terhadap lingkungan tempat nelayan mencari nafkah, biota laut akan mati karena laut keruh. Saudara-saudara yang hidup di pinggir pantai dan berprofesi nelayan tentu tak rela jika tempat mereka mencari nafkah dirusak...! teriak Saija lantang. "Apakah saudara-saudara akan membiarkan laut rusak karena penambangan pasir laut...?" lanjut Saija.

"Tidaaaakkk!" jawab warga kompak.

"Apakah saudara-saudara akan diam saja...?"

"Tidaaaaakkk! Jawab warga semakin bersemangat.

"Apakah saudara-saudara takut melawan penguasa yang akan menzalimi saudara-saudara?"

"Tidaaaaaakkkk!"(Kelomang, 105-106)

This justice applies to all aspects of life, including the rights and obligations that each individual has. This justice means not only being selfish or for certain groups. Fishermen also have the right to enjoy the beautiful sea as a place to make a living. Mining of sea sand will cause a disaster that destroys the sense of justice and the terrible work of the fishermen in an instant, as well as burying the fishermen's hope of making a living. Ecological disasters take away the rights of human life and eliminate the sources of human life, resulting in increased poverty rates. Development is still not very much in favor of the community and the environment. Banten local government is more in favor of entrepreneurs.

The struggle of fishermen to get intergenerational environmental justice, save the environment from threats and crises and the destruction of the environment and its sources of life. Therefore, fishermen's right to the environment must be recognized. The right to the environment must also be accompanied by respect for other rights, such as the right to information, the right to self-determination, the right to express opinions, and the right to participate in politics. If this does not meet a common ground, then these worries will turn into anger among fishermen against the local government.

The government must strive to ensure the safety of the people in facing the environmental crisis. Every government policy will always have certain consequences on the environment and community conditions. That every change in one place will result in changes in another. As a metaphor, "The flapping of a butterfly's wings in the Amazon Forest can cause tornadoes in America". This was expressed by Saija during a hearing between Regent Jamaludin and the demonstrators.

"Baik, saya akan keluar," ungkap Saija sambil bangkit dari kursi beledu yang baru ia duduki. "Asal bapak tahu, dampak kerusakan lingkungan akibat penambangan pasir laut tidak saja dirasakan warga di sekitar lokasi penambangan. Sebatang pohon yang ditebang di Pulau Kalimantan saja dampaknya bisa dirasakan di Pulau Jawa, bahkan di belahan dunia lainnya," ujar Saija. Matanya menatap tajam ke arah Pak Bupati yang duduk bersandar di kursinya. (Kelomang, 108)

Not only committed, the government is obliged to carry out development that is environmentally sound consequently, based on human rights, equality, and social and ecological justice. Saija explained that the impact of environmental damage due to sand mining is not only felt by local residents but also on other residents. For example, cutting down trees on the island of Borneo can have an influence on the island of Java and even the world.

The struggle that was carried out by Saija was never tired. Even though in the Kelomang novel it is told that Saija eventually had to die from being shot by hot lead by one of the thugs guarding the company because he persisted in his environmental vision. However, his thoughts and struggles continue to live in the hearts of those who are in line with his environmental vision.

Kepergian Saija dan Adinda untuk selamanya membawa duka bagi rekan-rekan dan warga pesisir. Namun kepergian itu juga menumbuhkan tekad bagi Firman, Deden, Ibnu, Kang Arif, dan orangorang dekat Saija untuk terus berjuang mengawal kasus ini hingga tuntas, walaupun nyawa mereka menjadi taruhannya. (Kelomang, 181)

\section{CONSLUSION}

It can be concluded that this study aims to find the environmental vision of Saija's character in the Kelomang novel by Qizink La Aziva using apocalyptic ecocritical studies. The main characteristic of apocalyptic literature is the emergence of characters with heroic characters. Through this character, God's revelations are conveyed and visions of the future are conveyed, both directly and in disguise. The intended future vision is related to the future vision of the environment. A figure with an environmental vision is a figure who has an awareness of the importance of protecting the environment and preventing further environmental damage. These heroic characters are symbols of God's revelation in protecting the environment. Become a representative of God who provides benefits to the universe. The result of this research is that Saija has a 
vision of the environment to save the environment from the increasingly severe impacts of environmental damage, especially in his area, namely Banten.

\section{REFERENCES}

Adhikari, R. (2021). Anthropocentric Hubris and Ecological Reversal in JG Ballard's The Drought. SCHOLARS: Journal of Arts \& Humanities, 3(1), 94-102.

Afni, N. (2018). Representasi Alam dan Manusia dalam "Novel Api Awan Asap" Karya Korrie Layun Rampan: Suatu Kajian Ekokritik Gred Garrard. Universitas Negeri Makassar.

Anggraini, A. P. et.al. (2021). Sex in Stencil Novels Case Study: Reader's Reception of Enny Arrow's Stencil Novel in Surakarta. International Journal of Current Science Research and Review, 4 (1), 1-5.

Asri, Y. (2013). Refleksi Ideologi Wanita Minangkabau dalam Novel Negeri Perempuan Karya Wisran Hadi. Humaniora, 25(1), 69-81.

Chatterjee, N. (2021). Questioning the Notion of Speciesism in Select Poems of Peter Reading's Faunal. Vidyasagar, 14, 178-186.

Garrard, G. (2004). Ecocrticism. New York: Routledge.

Glothfelty, C., \& Fromm, H (eds). (1996). The Ecocriticism Reader: Landmarks in Literary Ecology. London: University of Georgia Press.

Handique, P., \& Bhattacharyya, A. (2021). Re-understanding Deification and Hunger: An Ecocritical Venture into Shiva Purana. Journal of Humanities and Social Sciences Studies, 3(1), 116-121.

Hartavi, A. N. et.al. (2021). The Image's of Javanese Women in The Novel "Panggil Aku Kartini Saja" by Pramoedya Ananta Toer. American Journal of Humanities and Social Science Research, 5 (1), 36-40.

Susanti, R., \& Andriani, D. S. (2021, February). Building a Love Character of the Cultural Environment Through Historical Learning. In 1st International Conference on Character Education (ICCE 2020) (pp. 118-124). Atlantis Press.

Kaswadi. (2015). Paradigma Ekologi dalam Kajian Sastra. Paramasastra, 2 (2), 31-45.

Khristiyanti, D., \& Supriyanto, T. (2018). Nature Environment Representation in Raudal Tanjung Banua Poetries: Exocriticism Review. Seloka: Jurnal Pendidikan Bahasa dan Sastra Indonesia, 7(2), 154-164.

La Aziva, Q. (2016). Kelomang. Jakarta: PT Gramedia Pustaka Utama.

Mishra, N. (2021). Ecocriticism and its Portrayal in Indian Fiction Writing. Journal of Literary and Cultural Analysis, 1(1), 7-11.

Putri, M. P. (2017). Realitas Sosial dalam Novel Kelomang Karya Qizink La Aziva (Kajian Realisme Sosialis Georg Lukacs). Bapala, 4(1), 1-11.

Rini, W. P. (2018). Paradoks Narasi Penyelamatan Keseimbangan Ekosistem dalam Novel Kailasa Karya Jusuf AN Kajian Ekokritik. Poetika: Jurnal Ilmu Sastra, 6(2), 122-132.

Sloots, A. (2020). An ecocritical approach to Kazuo Ishiguro's “The Buried Giant”. Lund University, 1-18.

Sukmawan, S. (2013). Model-Model Kajian Ekokritik Sastra. PENSTRA, 2 (2).

Sulistijani, E. (2018). Kearifan Lokal dalam Kumpulan Puisi Kidung Cisadane Karya Rini Intama (Kajian Ekokritik Sastra). Nusa: Jurnal Ilmu Bahasa dan Sastra, 13(1), 1-15.

Supriyanto, T. (2014). Kajian Stilistika dalam Prosa. Yogyakarta: Elmatera Publishing.

Suryanto, S., Andayani, A., \& Wardhani, N. E. (2021). Reflection of Character Education Value through Depictions of Characters in Oka Rusmini's Koplak Novel. International Journal of Multicultural and Multireligious Understanding, 8(2), 78-86.

Tait, A. (2021). Environmental Crisis, Cli-fi, and the Fate of Humankind in Richard Jefferies' After London and Robert Harris' The Second Sleep. Exchanges: The Interdisciplinary Research Journal, 8(2), 69-83.

Uniawati. (2014). "Nelayan di Lautan Utara": Sebuah Kajian Ekokritik. Kandai, 10 (2), 246-257.

Yuniawan, T., Rokhman, F., Mardikantoro, H. B., Zulaehae, I., Yuwono, U., Prayitno, H. J., \& Rohmadi, M. (2019). The function of eco-lexicons in conservation news texts published in mass media. International Journal of Innovation, Creativity and Change, 7(11), 301-313. 